Biota Vol. IX (3): 144-154, Oktober 2004

ISSN 0853-8670

\title{
Struktur Anatomi Daun Artemisia cina Berg. Ex Poljakov Hasil Kultur Jaringan
}

Leaf Anatomical Structure of Artemisia cina Berg. Ex Poljakov Grown in Tissue Culture

\author{
Tri Muji Ermayanti ${ }^{1}$, Juliarni ${ }^{2 *}$, dan Yuli Andry ${ }^{3}$ \\ ${ }^{1}$ Pusat Penelitian Bioteknologi LIPI, Jl. Raya Bogor Km 46, Cibinong 16911 \\ ${ }^{2 \& 3}$ Departemen Biologi, FMIPA, Institut Pertanian Bogor, Jl. Raya Pajajaran, Bogor 16144 \\ Tel./Fax.+62 - 251-345011,E-mail :ywibowo@plasa.com.*penulis untuk korespondensi
}

\begin{abstract}
This study was conducted to investigate the anatomical structure of leaves of Artemisia cina Berg. ex Poljakov due to variances in leaf morphology during grown in vitro. Shaking of culture, position of stem nodes used as explants and concentration of BAP (Benzyl Amino Purin) added to the culture medium were the factors investigated in this study. There was variation in leaves morphology of culture, however this variation did not occur after aclimatization and plant grown in the greenhouse. BAP decreased the level of chlorophyll content of leaves. In general, anatomical characters of leaves were not influenced by shaking, nodes position of stem and level of BAP.
\end{abstract}

Key words : leaf anatomy, Artemisia cina, tissue culture.

Diterima: 28 Januari 2004, disetujui:31 Mei 2004

\section{Pendahuluan}

Artemisia cina Berg. ex Poljakov (Asteraceae) merupakan tanaman herba asli Asia. Di pulau Jawa tanaman ini dikenal sebagai tanaman hias dan obat (Backer dan Vanden-Brink Jr., 1965). Tanaman ini telah lama digunakan sebagai obat penyakit cacing pada anak-anak. Tanaman ini juga berkhasiat sebagai obat rematik, demam, perut kembung, radang tonsil, gangguan pencernaan (Syamsuhidayat dan Hutapea, 1991), antikanker (Aryanti, 2001) dan anti-leukemia (Aryanti et al., 2001). Bagian tanaman yang digunakan adalah daun, bunga, dan biji yang mengandung senyawa-senyawa alkaloid, saponin, flavonoid, polifenol (Syamsuhidayat dan Hutapea, 1991), santonin, resin, minyak atsiri dan artemisinin (Grieve, 1931; Burkill, 1966).

Sebagai tanaman bernilai ekonomi tinggi, upaya perbanyakan untuk meningkatkan produksi tanaman ini sangat diperlukan. Selain perbanyakan secara konvensional dengan stek tunas, perbanyakan alternatif secara in vitro yaitu dengan kultur jaringan juga telah diupayakan. Dengan kultur jaringan dapat dihasilkan bibit yang banyak dalam waktu relatif singkat, bibit bebas penyakit dan produksi bibit tidak tergantung musim. Selain itu, produksi senyawa metabolit sekunder bernilai tinggi juga dapat dimodifikasi secara in vitro dengan kultur jaringan (Gunawan, 1988; Taji et al., 1992).

Studi pendahuluan perbanyakan $A$. cina secara in vitro pada media MS cair (Murashige dan Skoog, 1962) dengan penambahan empat macam konsentrasi $(0 ; 0,5 ; 1$; dan $2 \mathrm{mg} / \mathrm{l})$ hormon 6-benzil amino purin (BAP), dengan atau tanpa penggojokan saat inkubasi kultur, menunjukkan adanya variasi morfologi daun (Ermayanti et al., 2002). Penelitian ini bertujuan untuk mempelajari apakah variasi morfologi daun yang terjadi menyebabkan variasi struktur anatomi daun $A$. cina yang diperbanyak dengan kultur jaringan. Variasi struktur daun ini diharapkan ada hubungannya dengan kadar metabolit sekunder yang diproduksinya, dengan demikian seleksi klon tunas dengan morfologi tertentu yang 
mengandung metabolit sekunder tinggi dapat diperbanyak dan ditingkatkan produksinya.

\section{Metode Penelitian}

\section{Penanaman Kultur dan Aklimatisasi}

Eksplan yang digunakan adalah batang tanaman in vitro yang dipotong. Setiap potongan berukuran panjang $0,5-1,0 \mathrm{~cm}$ dan mengandung buku posisi ke-1, atau ke-2, atau ke-3 (dari ujung tunas). Inisiasi tunas dilakukan dengan mengkulturkan eksplan pada cawan petri berisi $25-30 \mathrm{ml}$ media MS padat yang mengandung $2 \mathrm{mg} / \mathrm{l}$ BAP. Kultur diinkubasi selama dua minggu di ruang kultur bersuhu $26 \pm 2^{\circ} \mathrm{C}$ dengan penyinaran kontinyu menggunakan lampu TL (Tungsten Lamp) 18 watt. Delapan tunas yang pertumbuhannya baik dan memiliki tinggi $\pm 1 \mathrm{~cm}$ untuk masingmasing perlakuan dipindahkan ke dalam tabung magenta yang berisi $25-30 \mathrm{ml}$ media MS cair. Zat pengatur tumbuh BAP dengan konsentrasi $0 ; 0,5 ; 1$ dan $2 \mathrm{mg} / \mathrm{l}$ selanjutnya

Tabel 1. Variasi perlakuan penelitian. ditambahkan ke dalam media MS cair tersebut Perlakuan penggojokan dilakukan dengan meletakkan tabung kultur di atas alat penggojok dengan kecepatan putar $100 \mathrm{rpm}$, sedangkan untuk perlakuan tanpa penggojokan tabung kultur hanya diletakkan pada rak kultur. Kultur diinkubasi selama enam minggu dengan kondisi yang sama pada saat inisiasi tunas.

Dua tunas yang telah berumur enam minggu dari masing-masing perlakuan kultur (Tabel 1) dipindahkan ke dalam tabung reaksi berisi vermikulit dengan media MS cair tanpa sukrosa dan zat pengatur tumbuh untuk proses perakaran selama 4 minggu. Selanjutnya plantlet yang telah berakar ditanam dalam pot plastik dengan media tanam berupa campuran tanah dan pasir steril (1:1). Setelah tanaman tumbuh dan menghasilkan daun $( \pm 7$ hari), tanaman tersebut dipindahkan ke dalam polybag berisi tanah dan ditempatkan di rumah kaca.

\begin{tabular}{|c|c|c|c|c|c|}
\hline \multirow[t]{2}{*}{ Kondisi kultur } & \multirow{2}{*}{$\begin{array}{c}\text { Posisi } \\
\text { buku ke- }\end{array}$} & \multicolumn{4}{|c|}{ BAP (mg/l) } \\
\hline & & $\mathbf{0}$ & 0,5 & 1 & 2 \\
\hline \multirow[t]{3}{*}{ Tanpa penggojokan } & 1 & $\mathrm{P}-\mathrm{B}_{1} \mathrm{M}_{0}$ & $\mathrm{P}-\mathrm{B}_{1} \mathrm{M}_{0,5}$ & $\mathrm{P}-\mathrm{B}_{1} \mathrm{M}_{1}$ & $\mathrm{P}-\mathrm{B}_{1} \mathrm{M}_{2}$ \\
\hline & 2 & $\mathrm{P}-\mathrm{B}_{2} \mathrm{M}_{0}$ & $\mathrm{P}-\mathrm{B}_{2} \mathrm{M}_{0,5}$ & $\mathrm{P}-\mathrm{B}_{2} \mathrm{M}_{1}$ & $\mathrm{P}-\mathrm{B}_{2} \mathrm{M}_{2}$ \\
\hline & 3 & $\mathrm{P}-\mathrm{B}_{3} \mathrm{M}_{0}$ & $\mathrm{P}-\mathrm{B}_{3} \mathrm{M}_{0,5}$ & $\mathrm{P}-\mathrm{B}_{3} \mathrm{M}_{1}$ & $\mathrm{P}-\mathrm{B}_{3} \mathrm{M}_{2}$ \\
\hline \multirow[t]{3}{*}{ Dengan penggojokan } & 1 & $\mathrm{P}_{+} \mathrm{B}_{1} \mathrm{M}_{0}$ & $\mathrm{P}_{+} \mathrm{B}_{1} \mathrm{M}_{0,5}$ & $\mathrm{P}_{+} \mathrm{B}_{1} \mathrm{M}_{1}$ & $\mathrm{P}_{+} \mathrm{B}_{1} \mathrm{M}_{2}$ \\
\hline & 2 & $\mathrm{P}_{+} \mathrm{B}_{2} \mathrm{M}_{0}$ & $\mathrm{P}_{+} \mathrm{B}_{2} \mathrm{M}_{0,5}$ & $\mathrm{P}_{+} \mathrm{B}_{2} \mathrm{M}_{1}$ & $\mathrm{P}_{+} \mathrm{B}_{2} \mathrm{M}_{2}$ \\
\hline & 3 & $\mathrm{P}_{+} \mathrm{B}_{3} \mathrm{M}_{0}$ & $\mathrm{P}_{+} \mathrm{B}_{3} \mathrm{M}_{0,5}$ & $\mathrm{P}_{+} \mathrm{B}_{3} \mathrm{M}_{1}$ & $\mathrm{P}_{+} \mathrm{B}_{3} \mathrm{M}_{2}$ \\
\hline
\end{tabular}

Ket : $\mathrm{P}=$ penggojokan; $\mathrm{P}_{+}=$dengan penggojokan, $\mathrm{P}-\mathrm{=}$ tanpa penggojokan $. \mathrm{B}=$ posisi buku ke; $\mathrm{B}_{1}=$ buku ke-1, $\mathrm{B}_{2}=$ buku ke-2, $\mathrm{B}_{3}=$ buku ke- 3 . M= media MS cair dengan/tanpa BAP; $\mathrm{M}_{0}=$ media MS cair tanpa BAP; $\mathrm{M}_{0,5}=$ media MS cair + 0,5 mg/l BAP; $\mathrm{M}_{1}=$ media MS cair + $1 \mathrm{mg} / \mathrm{l} \mathrm{BAP} ; \mathrm{M}_{2}=$ media $\mathrm{MS}$ cair +2 $\mathrm{mg} / \mathrm{l} \mathrm{BAP}$.

\section{Pembuatan Sediaan Mikroskopis}

Sayatan paradermal dan transversal dibuat dari daun ke-4 dari setiap tanaman perlakuan baik dari tanaman kultur maupun rumah kaca. Sayatan paradermal dibuat mengikuti metode sediaan utuh (Sass, 1951). Daun difiksasi dalam larutan etanol $50 \%$, kemudian direndam dalam larutan $\mathrm{HNO}_{3} 20 \%$ selama 10 menit. Lapisan epidermis atas dan bawah dilepas menggunakan pinset, selanjutnya diwarnai dengan larutan safranin
$1 \%$. Sayatan diletakkan pada gelas obyek yang diberi larutan gliserin $30 \%$.

Sayatan transversal dibuat mengikut metode parafin (Sass, 1951). Potongan daun berukuran $0,5 \times 0,5 \mathrm{~cm}$ difiksasi dalam larutan FAA (Formalin-Asam asetat-Alkohol 50\% dengan perbandingan 5:5:90) selama 24 jam Dehidrasi dilakukan secara bertahap dengan seri larutan etanol 50\%; 70\%; 95\%; dan etanol p.a. (pro analysis). Penjernihan dilakukan juga secara bertahap menggunakan campuran larutan etanol dan xilol dengan perbandingan 
3:1; 1:1; 1:3; dan terakhir dijernihkan dengan xilol absolut. Masing-masing tahapan dehidrasi dan penjernihan berlangsung selama 3 jam. Tahap selanjutnya dilakukan infiltrasi dan pembuatan blok parafin. Pembuatan sayatan setebal $8 \mu \mathrm{m}$ dilakukan dengan menggunakan mikrotom putar (Yamato RV-240). Pewarnaan yang dilakukan adalah pewarnaan ganda menggunakan safranin $1 \%$ dan fast green $0,5 \%$.

\section{Pengamatan Ciri Morfologi Daun}

Peubah morfologi daun yang diamati adalah bentuk dan warna daun. Pengamatan bentuk daun dilakukan pada daun ke-3 dari masing-masing tanaman perlakuan. Ciri morfologi daun diacu berdasarkan paparan Tjitrosoepomo (2001). Warna daun diamati secara visual dan dilanjutkan dengan analisis kandungan klorofil.
Analisis kandungan klorofil dilakukan dengan menggunakan metode Aronoff dan MacKinney (Arnon, 1949). Helaian daun segar tanpa tulang daun sebanyak $0,43 \mathrm{~g}$ digerus dalam $10 \mathrm{ml}$ larutan bufer fosfat $0.07 \mathrm{M} \mathrm{pH}$ 6,5 . Hasil gerusan selanjutnya disentrifugasi selama 1 menit pada suhu $4^{\circ} \mathrm{C}$ dengan kecepatan $3000 \mathrm{rpm}$. Selanjutnya, supernatan disentrifugasi selama 20 menit pada suhu $4^{\circ} \mathrm{C}$ dengan kecepatan $12000 \mathrm{rpm}$. Pelet dicuci dengan larutan bufer fosfat $0.07 \mathrm{pH} 6,5$ dan diresuspensikan dengan bufer, kemudian 0,5 $\mathrm{ml}$ suspensi kloroplas dilarutkan dalam $20 \mathrm{ml}$ larutan aseton $80 \%$. Absorbansi larutan klorofil diukur menggunakan spektrofotometer (Spectronic 21D-Milton Roy, USA) pada panjang gelombang $(\lambda) 645$ dan $663 \mathrm{~nm}$. Kandungan klorofil dihitung dengan persamaan berikut:

$\mathrm{D}_{663}=82,04 \mathrm{Ca}+9,27 \mathrm{Cb}$.

.(persamaan 1)

$\mathrm{D}_{645}=16,75 \mathrm{Ca}+45,6 \mathrm{Cb}$. (persamaan 2)

dengan:

$\mathrm{Ca}=$ kandungan klorofil a $(\mathrm{g} / \mathrm{l})$

$\mathrm{Cb}=$ kandungan klorofil $\mathrm{b}(\mathrm{g} / \mathrm{l})$

$\mathrm{D}=$ nilai absorban

Dari persamaan 2 :

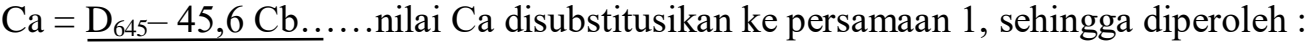
16,75

$\mathrm{Cb}=0,0229 \mathrm{D}_{645}-0,00468 \mathrm{D}_{663}$ (persamaan 3)

Nilai $\mathrm{Cb}$ disubstitusikan ke persamaan 2 sehingga diperoleh:

$\mathrm{Ca}=0,0127 \mathrm{D}_{645}-0,00269 \mathrm{D}_{663}$ (persamaan 4)

Kandungan klorofil total (C) dalam g/l:

$\mathrm{C}=\mathrm{Ca}+\mathrm{Cb}$

$\mathrm{C}=0,0202 \mathrm{D}_{645}+0,00802 \mathrm{D}_{663}$ (persamaan 5) Kandungan klorofil total $(\mathrm{C})$ dalam $\mathrm{mg} / \mathrm{l}$ :

\section{Pengamatan Struktur Anatomi Daun}

Peubah yang diamati pada sayatan paradermal meliputi bentuk, ukuran, dan kerapatan sel epidermis; kerapatan stomata, panjang dan lebar stomata (Gambar 1), serta indeks stomata. Tebal helai daun, jumlah lapisan dan tebal jaringan palisade, tebal jaringan bunga karang, dan rasio jaringan (tebal jaringan bunga karang dan epidermis terhadap tebal jaringan palisade) diamati dari sayatan transversal. 


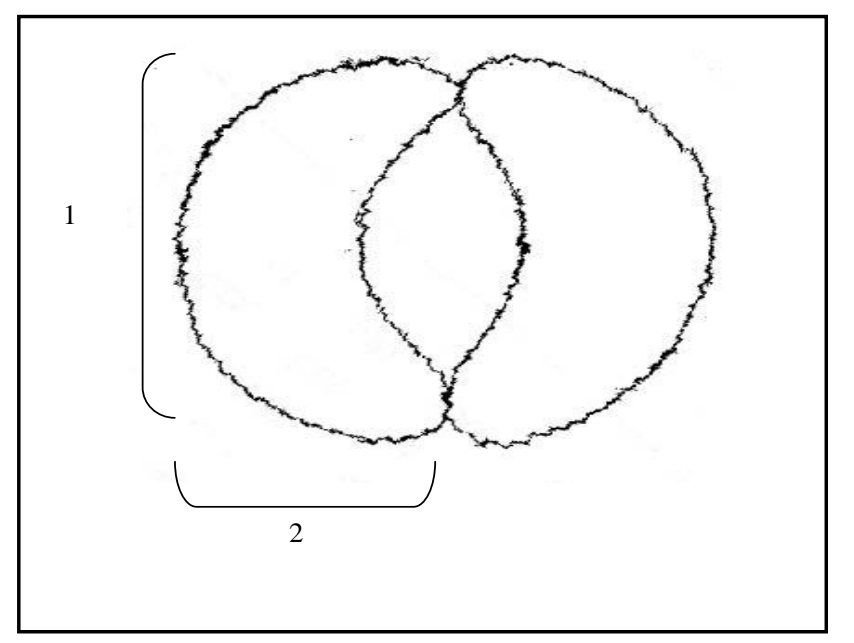

Gambar 1. Skema stomata dengan panjang (1) dan lebar (2).

Data ukuran dan kerapatan sel epidermis, kerapatan stomata, dan indeks stomata yang diperoleh merupakan nilai rata-rata dari lima bidang pandang yang dipilih secara acak, masing-masing dengan lima ulangan. Nilai peubah tebal helai daun, jaringan palisade, dan bunga karang, serta rasio jaringan merupakan rata-rata dari lima bidang pandang yang dipilih secara acak, masing-masing dengan tiga ulangan. Indeks Stomata (IS) dihitung berdasarkan persamaan berikut:

$$
\mathrm{IS}=\frac{\text { Jumlah stomata per satuan luas daun }}{\begin{array}{c}
\text { Jumlah stomata }+ \text { jumlah sel epidermis } \\
\text { per satuan daun }
\end{array}} \times 100
$$

(Salisbury, 1928; dalam Willmer, 1983)

\section{Hasil dan Pembahasan}

\section{Ciri Morfologi Daun}

Pengamatan morfologi daun menunjukkan adanya variasi bentuk dan ukuran. Secara umum daun tanaman kultur memiliki bentuk bulat telur dengan ujung dan pangkal daun runcing. Berdasarkan dalamnya torehan, bentuk daun bervariasi dari berlekuk menyirip (pinnatilobus) sampai bercangap menyirip (pinnatifidus) (Gambar 2a). Bentuk daun tanaman kultur berbeda dengan tanaman rumah kaca (hasil aklimatisasi) yang memiliki bentuk daun berbagi menyirip (pinnatipartitus) (Gambar 2b). Secara visual ukuran daun umumnya cenderung mengecil dengan meningkatnya konsentrasi BAP.

Variasi bentuk dan ukuran daun hanya dijumpai pada saat tanaman dipelihara secara in vitro. Setelah tanaman tersebut ditanam di rumah kaca, bentuk dan ukuran daun kembali normal seperti tanaman induk. Variasi bentuk daun yang hanya terjadi pada tanaman kultur diduga disebabkan oleh kondisi lingkungan kultur yang berbeda dengan kondisi rumah kaca. Lingkungan kultur memiliki kelembaban dan kandungan karbohidrat tinggi dengan intensitas cahaya yang rendah (Smith et al., 1986 Cit Grace, 1990; Kitaya et al., 1996) serta akumulasi senyawa toksik dan absennya mikroorganisme (Kitaya et al., 1996) dibandingkan dengan lingkungan rumah kaca. Kelembaban dalam botol kultur berisi planlet dapat mencapai $\geq 95 \%$ (Fujiwara and Kozai, 1995). Kelembaban yang tinggi menyebabkan terganggunya perkembangan, fisiologi, dan struktur morfologi tanaman kultur yang pada umumnya menyebabkan tingginya angka kematian tanaman saat diaklimatisasi (Kozai et al., 1993). Pada penelitian ini tidak dijumpai adanya tanaman yang mati saat dipindahkan ke rumah kaca. Hal ini diduga karena A. cina memiliki daya adaptasi yang baik terhadap perubahan kondisi lingkungan. 


\section{Kandungan Klorofil Daun}

Warna daun cenderung menguning dengan meningkatnya konsentrasi BAP. Analisis kandungan klorofil menunjukkan bahwa kandungan klorofil daun tanaman kultur lebih rendah dibandingkan dengan tanaman hasil aklimatisasi (Gambar 3).

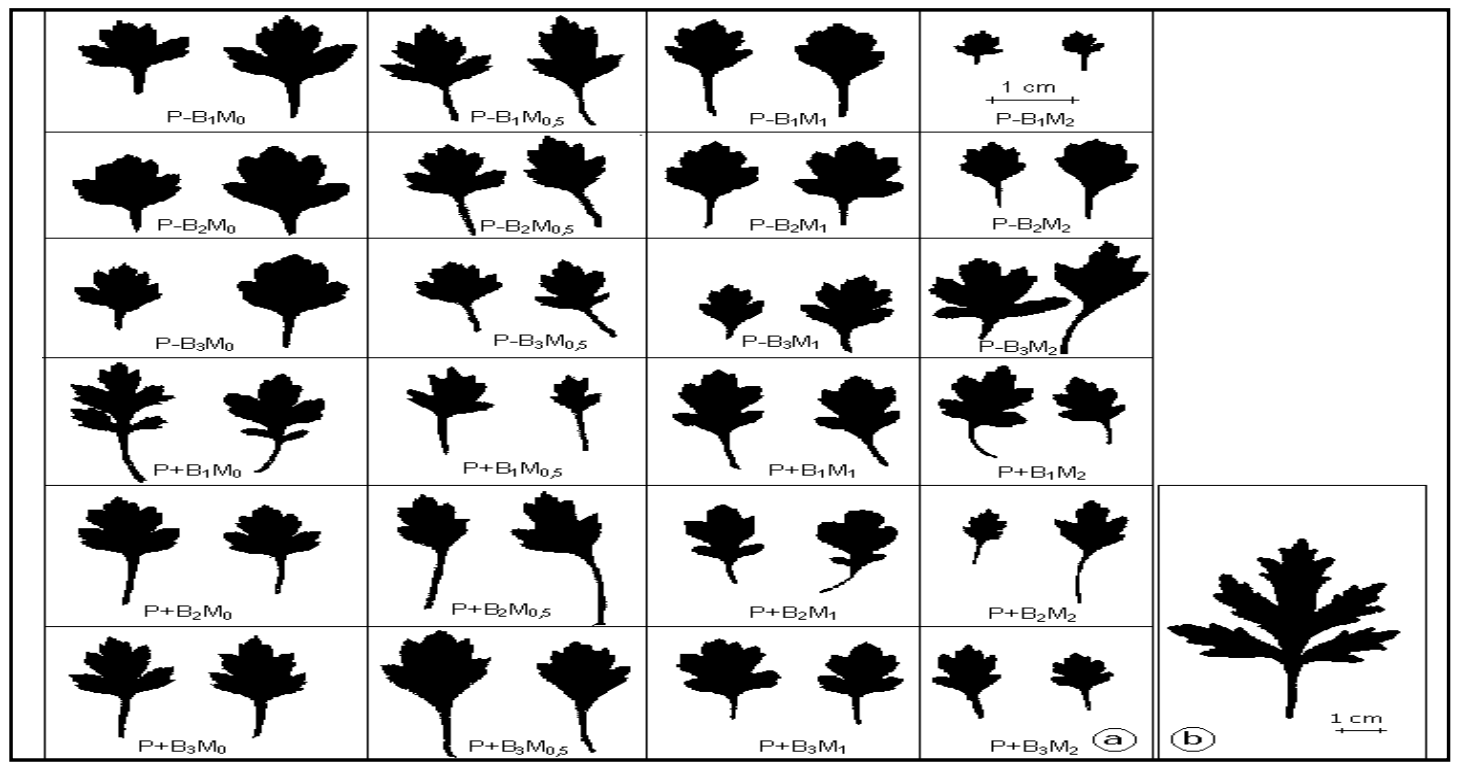

Gambar 2. Variasi morfologi daun A. cina hasil kultur jaringan (a) dan rumah kaca (b). Keterangan tentang perlakuan tertera pada Tabel 1 .

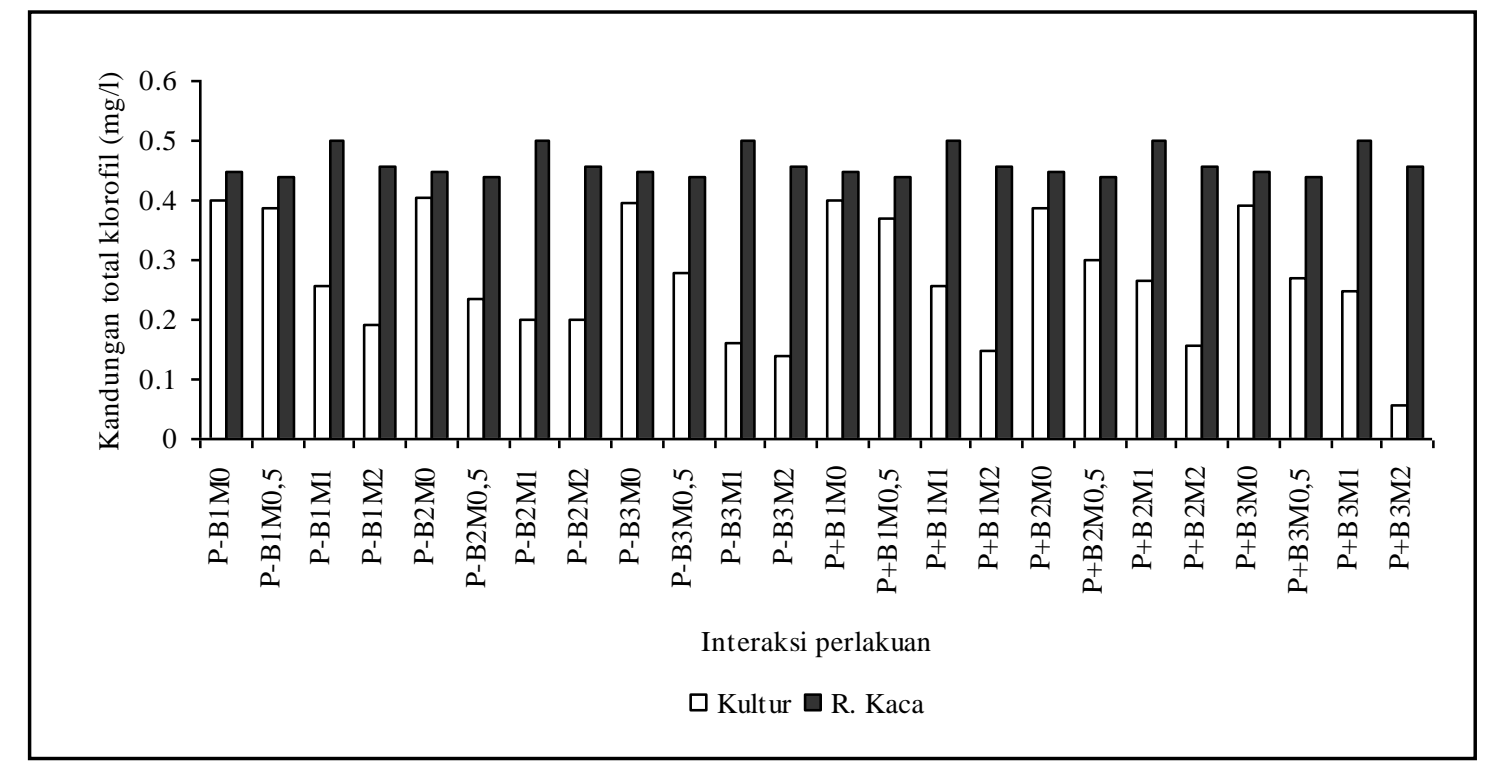

Gambar 3. Kandungan klorofil total daun tanaman kultur ( $\square$ ) dan rumah kaca ( $\boldsymbol{\square})$.

Seperti halnya bentuk daun, kandungan klorofil daun juga menunjukkan gejala yang sama yaitu kembali meningkat setelah ditanam di rumah kaca. Pemberian BAP yang merupakan zat pengatur tumbuh golongan sitokinin menyebabkan penurunan kandungan klorofil daun. Hal ini kemungkinan bahwa sitokinin pada konsentrasi tinggi menurunkan 
kerja enzim yang bertanggungjawab pada pembentukan klorofil. Hasil penelitian Grace (1990) yang menggunakan sitokinin menunjukkan bahwa kandungan klorofil daun Eucalyptus sp. hasil kultur jaringan menurun dengan meningkatnya konsentrasi sitokinin. Towne dan Owensby (1983) juga melaporkan bahwa semakin tinggi konsentrasi sitokinin yang disemprotkan pada daun Andropogon gerardi Vitman menyebabkan berkurangnya kandungan klorofil daun tanaman tersebut.

\section{Struktur Anatomi daun Epidermis}

Bentuk sel epidermis daun A. cina terlihat berlekuk-lekuk tidak beraturan pada sayatan paradermal (Gambar 4).
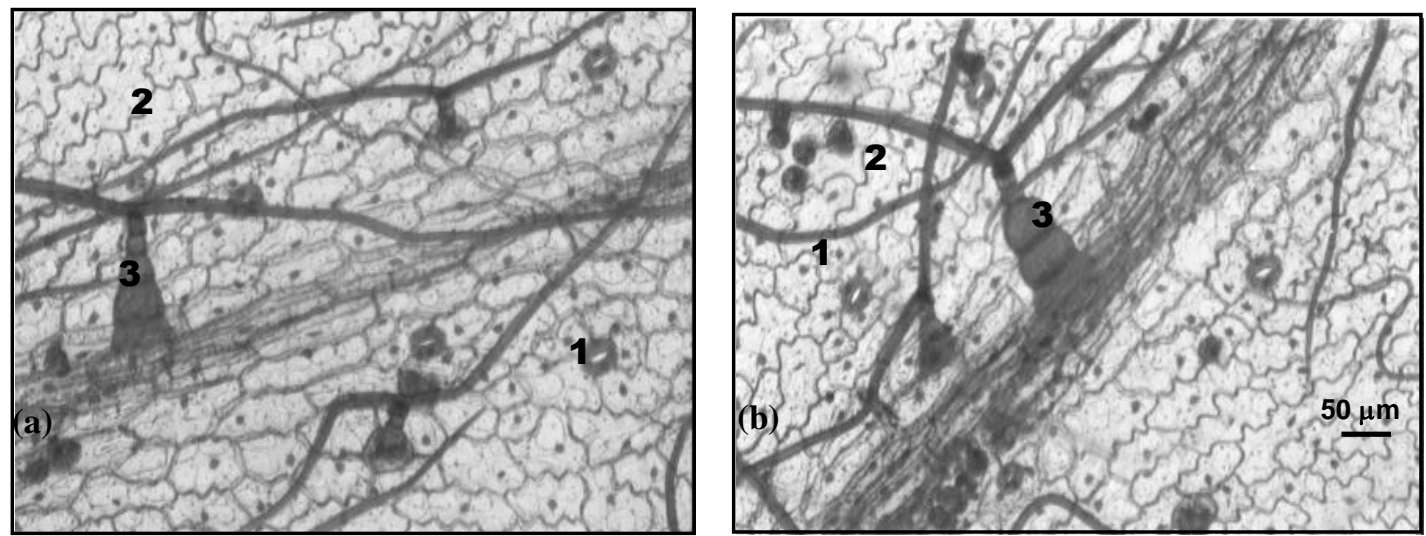

Gambar 4. Sayatan paradermal daun bagian atas dari tanaman kultur (a) dan rumah kaca (b). 1. Stoma. 2. Sel epidermis. 3. Trikoma

Perlakuan penggojokan, posisi buku, konsentrasi BAP dan interaksinya pada umumnya tidak berpengaruh nyata terhadap ukuran sel epidermis daun tanaman kultur maupun rumah kaca. Hanya interaksi perlakuan posisi buku dengan konsentrasi BAP yang berpengaruh nyata terhadap lebar sel epidermis atas daun tanaman kultur, dengan nilai tertinggi $57,6 \mu \mathrm{m}$, yang diperoleh dari kultur dengan eksplan berasal dari buku ke-1 dan media yang mengandung $2 \mathrm{mg} / \mathrm{l}$ BAP $\left(B_{1} M_{2}\right)$. Nilai terendah yaitu $42,2 \mu \mathrm{m}$ diperoleh dari kultur yang eksplannya berasal dari buku ke-1 dan media tanpa BAP $\left(\mathrm{B}_{1} \mathrm{M}_{0}\right)$ (Gambar 5). Ukuran panjang dan lebar sel epidermis atas dan bawah daun tanaman kultur memiliki nilai yang tidak berbeda tetapi pada tanaman rumah kaca nilainya lebih besar dari sel epidermis bawah. Panjang sel epidermis bagian atas daun tanaman rumah kaca lebih besar dari pada panjang sel epidermis atas tanaman kultur (Tabel 2).

\section{Stomata}

Daun A. cina merupakan daun amfistomatik yaitu stomata terdapat pada epidermis atas dan bawah daun (Fahn, 1990). Tipe stomatanya yaitu anomositik dengan sel penjaga berbentuk ginjal dan dikelilingi oleh 36 sel tetangga (Gambar 4). Pada umumnya perlakuan penggojokan, posisi buku, konsentrasi BAP dan interaksinya tidak berpengaruh nyata terhadap ukuran, kerapatan, dan indeks stomata tanaman kultur dan rumah kaca. Perlakuan posisi buku hanya berpengaruh nyata terhadap jumlah stomata daun bagian bawah (JSBK) dan panjang stomata (PSBK) daun bagian bawah tanaman kultur (Tabel 3).

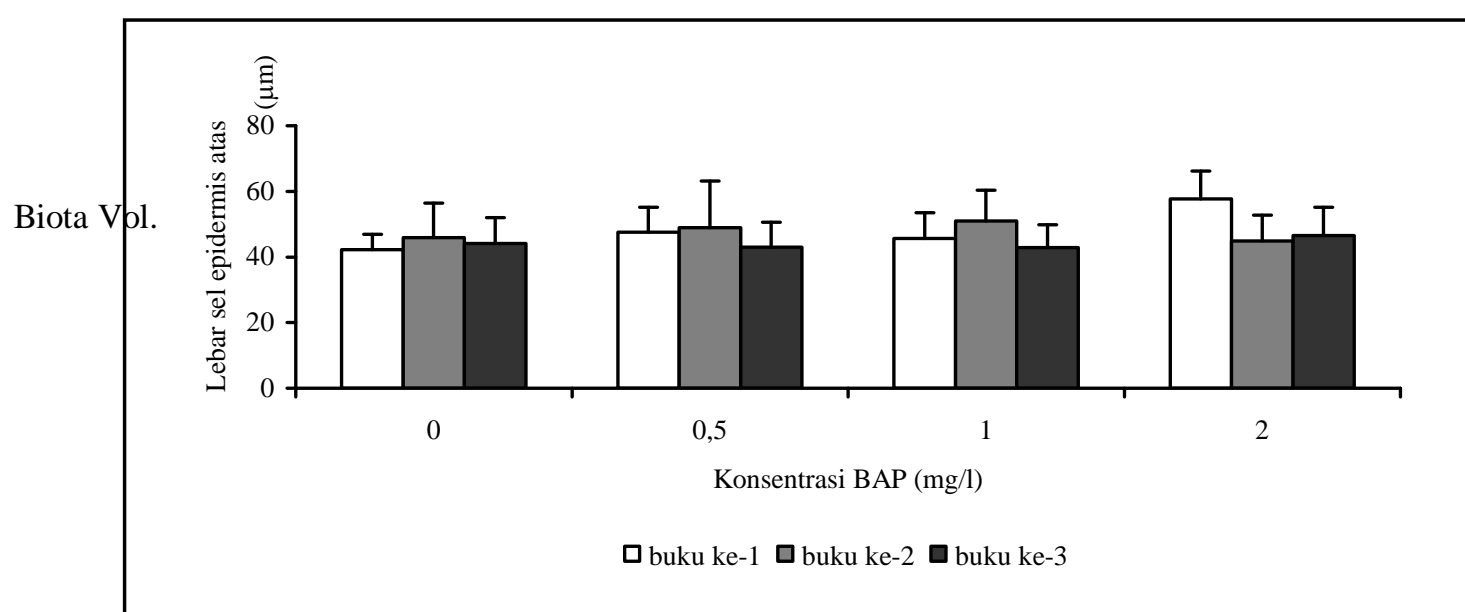


Gambar 5. Pengaruh interaksi perlakuan posisi buku dan konsentrasi BAP terhadap lebar sel epidermis atas daun tanaman kultur

Tabel 2. Karakter anatomi daun tanaman kultur dan rumah kaca.

\begin{tabular}{clcc}
\hline \hline $\begin{array}{c}\text { Jenis } \\
\text { sayatan }\end{array}$ & \multicolumn{1}{c}{ Peubah anatomi } & Nilai rata-rata \\
& & Kultur & Rumah kaca \\
\hline \hline \multirow{5}{*}{ Sayatan } & Panjang sel epidermis atas $(\mu \mathrm{m})$ & $68,3 \pm 13,5$ & $73,9 \pm 11,93$ \\
& Panjang sel epidermis bawah $(\mu \mathrm{m})$ & $69,2 \pm 14,3$ & $64,4 \pm 13,63$ \\
& Lebar sel epidermis atas $(\mu \mathrm{m})$ & $46,7 \pm 8,70$ & $51,6 \pm 8,66$ \\
paradermal & $47,5 \pm 9,74$ & $42,1 \pm 10,67$ \\
& Lebar sel epidermis bawah $(\mu \mathrm{m})$ & $30,4 \pm 1,19$ & $35,9 \pm 1,16$ \\
& Panjang stomata atas $(\mu \mathrm{m})$ & $31,4 \pm 1,53$ & $36,0 \pm 1,34$ \\
& Panjang stomata bawah $(\mu \mathrm{m})$ & $25,2 \pm 1,23$ & $24,7 \pm 1,91$ \\
& Lebar stomata atas $(\mu \mathrm{m})$ & $25,3 \pm 1,32$ & $24,8 \pm 1,48$ \\
& Lebar stomata bawah $(\mu \mathrm{m})$ & $8,4 \pm 2,84$ & $8,8 \pm 2,87$ \\
& Kerapatan stomata atas $\left(\mathrm{jumlah} / \mathrm{mm}^{2}\right)$ & $122,9 \pm 9.67$ & $119,8 \pm 11,09$ \\
& Kerapatan stomata bawah $\left(\mathrm{jumlah} / \mathrm{mm}^{2}\right)$ & $2,6 \pm 0,85$ & $2,6 \pm 0,83$ \\
& Indeks stomata atas $\left(\mathrm{jumlah} / \mathrm{mm}^{2}\right)$ & $27,8 \pm 2,08$ & $25,8 \pm 2,06$ \\
\hline \multirow{2}{*}{ Sayatan } & Indeks stomata bawah $\left(\mathrm{jumlah} / \mathrm{mm}^{2}\right)$ & $115,9 \pm 6,08$ & $139,1 \pm 4,89$ \\
transversal & $42,8 \pm 3,29$ & $42,8 \pm 3,49$ \\
& Tebal helaian daun $(\mu \mathrm{m})$ & $45,3 \pm 4,08$ & $60,6 \pm 4,25$ \\
& Tebal jaringan palisade $(\mu \mathrm{m})$ & $1,7 \pm 0,18$ & $2,3 \pm 0,27$ \\
\hline \hline
\end{tabular}

Tabel 3. Pengaruh posisi buku terhadap jumlah dan panjang stomata bawah daun tanaman kultur (JSBK dan PBSK).

\begin{tabular}{ccc}
\hline \hline Perlakuan Posisi buku ke- & JSBK/mm & PSBK $(\boldsymbol{\mu m})$ \\
\hline 1 & $119,7 \pm 1,37^{\mathrm{b}}$ & $30,9 \pm 1,49^{\mathrm{b}}$ \\
2 & $123,8 \pm 7,84^{\mathrm{ab}}$ & $31,9 \pm 1,58^{\mathrm{a}}$ \\
3 & $125,1 \pm 10,94^{\mathrm{a}}$ & $31,4 \pm 1,39^{\mathrm{ab}}$ \\
\hline \hline
\end{tabular}

Ket: Angka yang diikuti huruf yang sama pada masing-masing kolom pada setiap perlakuan tidak berbeda nyata pada uji DMRT 5\%.

JSBK tanaman kultur meningkat dari buku ke-1 sampai buku ke-3, sedangkan untuk

PSBK yang berasal dari buku ke-2 memiliki nilai tertinggi. Perlakuan konsentrasi BAP 
hanya berpengaruh nyata terhadap lebar stomata daun bagian bawah tanaman kultur (LSBK) dan panjang stomata daun bagian bawah tanaman rumah kaca (PSBRK). LSBK dari tanaman yang ditumbuhkan pada media dengan konsentrasi BAP $0,5 \mathrm{mg} / \mathrm{l}$ menunjukkan hasil tertinggi, sedangkan untuk PSBRK tidak terdapat perbedaan nyata antara konsentrasi BAP yang digunakan. Interaksi perlakuan penggojokan dengan konsentrasi BAP hanya berpengaruh nyata terhadap lebar stomata daun bagian atas tanaman rumah kaca (Gambar 6).

Nilai tertinggi untuk lebar stomata tersebut yaitu 25,2 $\mu \mathrm{m}$ diperoleh dari kombinasi perlakuan penggojokan dengan pemberian $1 \mathrm{mg} / \mathrm{l}$ BAP $\left(\mathrm{P}+\mathrm{M}_{1}\right)$, sedangkan nilai terendah yaitu $24,8 \mu \mathrm{m}$ diperoleh dari kombinasi perlakuan tanpa penggojokan dengan pemberian $1 \mathrm{mg} / \mathrm{l}$ BAP $\left(\mathrm{P}-\mathrm{M}_{1}\right)$ (Tabel 4).

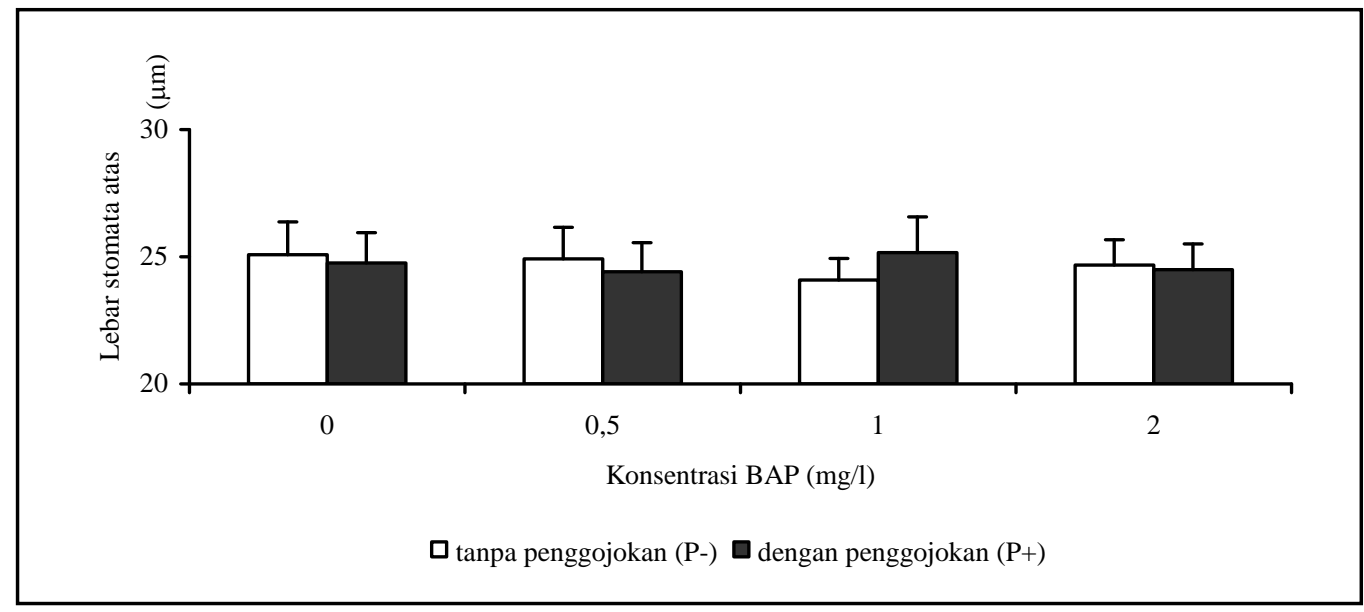

Gambar 6. Pengaruh interaksi perlakuan penggojokan dengan konsentrasi BAP terhadap lebar stomata atas daun tanaman rumah kaca.

Tabel 4. Pengaruh konsentrasi BAP terhadap lebar stomata bawah daun tanaman kultur (LSBK) dan panjang stomata bawah daun tanaman rumah kaca (PSBRK).

\begin{tabular}{ccc}
\hline \hline Konsentrasi BAP $(\mathbf{m g} / \mathbf{l})$ & LSBK $(\boldsymbol{\mu m})$ & PSBRK $(\mu \mathbf{m})$ \\
\hline 0 & $25,2 \pm 1,33^{\mathrm{b}}$ & $36,8 \pm 1,25^{\mathrm{a}}$ \\
0,5 & $26,1 \pm 1,22^{\mathrm{a}}$ & $35,8 \pm 1,33^{\mathrm{b}}$ \\
1 & $24,8 \pm 1,26^{\mathrm{b}}$ & $35,5 \pm 1,45^{\mathrm{b}}$ \\
2 & $25,2 \pm 1,19^{\mathrm{b}}$ & $35,9 \pm 0,98^{\mathrm{b}}$ \\
\hline \hline
\end{tabular}

Ket: Angka yang diikuti huruf yang sama pada masing-masing kolom pada setiap perlakuan tidak berbeda nyata pada uji DMRT $\alpha=5 \%$.

Interaksi perlakuan posisi buku dengan konsentrasi BAP hanya berpengaruh nyata terhadap lebar stomata daun bagian bawah tanaman kultur (Gambar 7) dan indeks stomata daun bagian bawah tanaman rumah kaca (Gambar 8). Lebar stomata daun bagian bawah tanaman kultur tertinggi diperoleh dari kombinasi perlakuan eksplan yang berasal dari Indeks stomata daun bagian bawah tanaman rumah kaca tertinggi diperoleh dari kombinasi perlakuan eksplan yang berasal dari buku ke-2 buku ke-2 dengan pemberian $0,5 \mathrm{mg} / 1 \mathrm{BAP}$ $\left(\mathrm{B}_{2} \mathrm{M}_{0,5}\right)$ dengan nilai $27,1 \mu \mathrm{m}$ dan terendah dari kombinasi perlakuan eksplan yang berasal dari buku ke-2 dengan pemberian 1 $\mathrm{mg} / \mathrm{l}$ BAP $\left(\mathrm{B}_{2} \mathrm{M}_{1}\right)$ dengan nilai $24,4 \mu \mathrm{m}$ (Gambar 6).

dan pemberian 0,5 mg/l BAP $\left(\mathrm{B}_{2} \mathrm{M}_{0,5}\right)$ dengan nilai 27,2 dan terendah dengan nilai 23,9 dari kombinasi perlakuan eksplan yang berasal dari 
buku ke-1 dan pemberian $0 \mathrm{mg} / \mathrm{l} \mathrm{BAP}\left(\mathrm{B}_{1} \mathrm{M}_{0}\right)$ (Gambar 8).

\section{Trikoma}

Trikoma terdapat pada epidermis atas dan bawah daun, merupakan trikoma multiselular yang terdiri atas beberapa sel basal, dengan rambut pipih memanjang melintang di atasnya berbentuk huruf $\mathrm{T}$ (Gambar 4)
Daun A. cina tersusun atas lapisan epidermis atas dan bawah serta jaringan mesofil (Gambar 9). Jaringan mesofilnya terdiferensiasi menjadi jaringan palisade dan bunga karang. Sel-sel jaringan palisade berbentuk agak membulat dan terdiri dari selapis sel yang hanya terdapat pada salah satu sisi daun (daun bifasial). Jaringan bunga karang tersusun atas sel-sel yang memiliki bentuk sedikit memanjang dengan ruang antarsel yang besar.

\section{Helai daun}

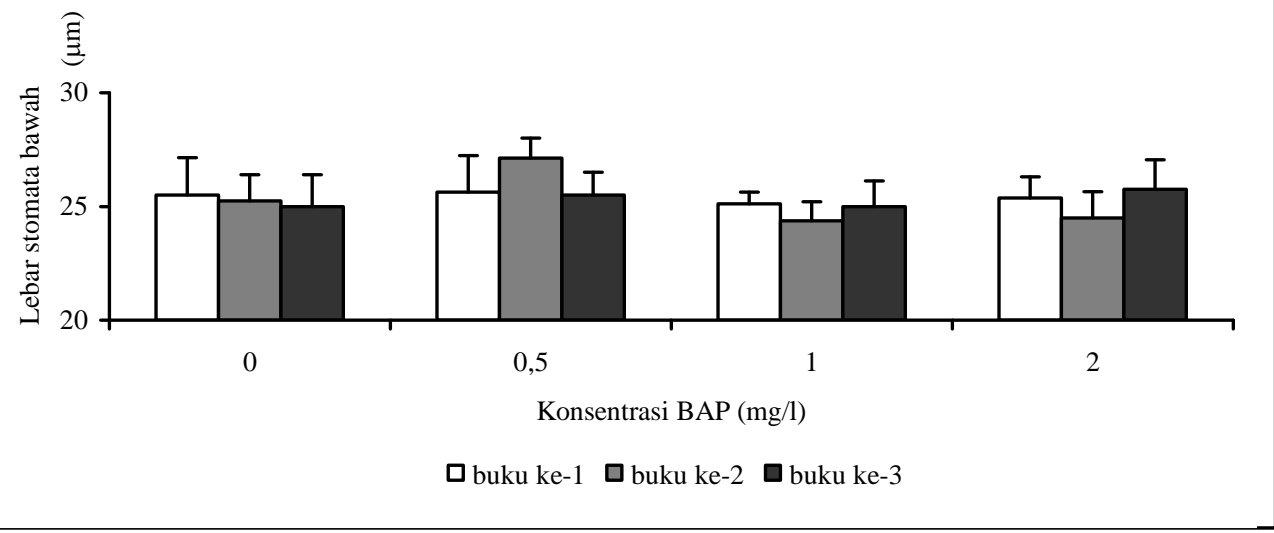

Gambar 7. Pengaruh interaksi perlakuan posisi buku dengan konsentrasi BAP terhadap lebar stomata bawah daun tanaman kultur.

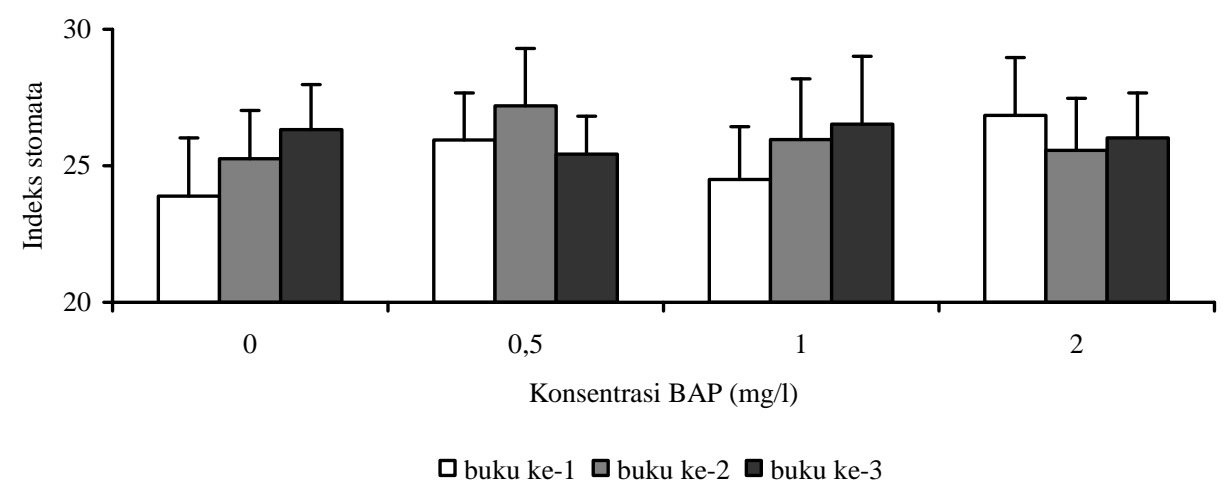

Gambar 8. Pengaruh interaksi perlakuan posisi buku dengan konsentrasi BAP terhadap indeks stomata bawah daun tanaman rumah kaca.
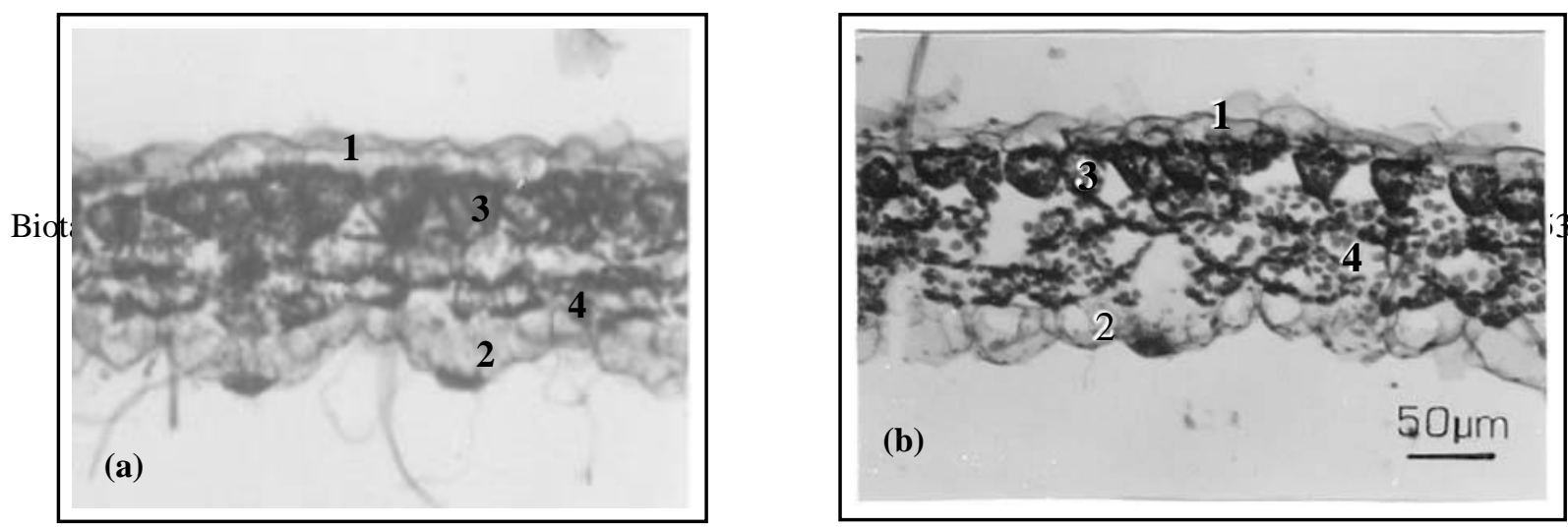
Gambar 9. Sayatan transversal daun tanaman kultur (a) dan rumah kaca (b). 1. Epidermis atas. 2. Epidermis bawah. 3. Jaringan palisade. 4. Jaringan bunga karang.

Secara umum perlakuan penggojokan, posisi buku, konsentrasi BAP dan interaksinya tidak berpengaruh nyata terhadap tebal helai daun, jaringan palisade dan bunga karang serta rasio jaringan tanaman kultur dan rumah kaca. Hanya perlakuan penggojokan dan posisi buku yang berpengaruh nyata terhadap tebal helai daun dan jaringan bunga karang tanaman kultur (Tabel 5). Tebal helai daun dan jaringan bunga karang tanaman kultur yang mendapat perlakuan penggojokan lebih besar dari tanaman kultur yang tidak mendapat perlakuan penggojokan. Posisi buku, tebal helai daun dari tanaman yang berasal dari eksplan buku ke-1 menunjukkan nilai terbesar dan berbeda nyata dengan tanaman yang berasal dari eksplan buku ke-3. Tebal jaringan bunga karang pada tanaman yang berasal dari eksplan buku ke-1 memiliki nilai terbesar.

Tabel 5. Pengaruh perlakuan penggojokan dan posisi buku terhadap tebal helai daun dan jaringan bunga karang tanaman kultur.

\begin{tabular}{lcc}
\hline \hline \multicolumn{1}{c}{ Perlakuan } & $\begin{array}{c}\text { Tebal Helai daun } \\
(\boldsymbol{\mu} \mathbf{m})\end{array}$ & Tebal Jaringan bunga karang $(\boldsymbol{\mu m})$ \\
\hline Penggojokan & & \\
$\quad$ - Tanpa (-) & $118,5 \pm 4,79^{\mathrm{a}}$ & $47,2 \pm 3,20^{\mathrm{a}}$ \\
- Dengan (+) & $113,4 \pm 6,24^{\mathrm{b}}$ & $43,3 \pm 3,93^{\mathrm{b}}$ \\
\hline Posisi buku ke- & & \\
-1 & $119,4 \pm 5,24^{\mathrm{a}}$ & $47,4 \pm 4,32^{\mathrm{a}}$ \\
-2 & $115,0 \pm 4,97^{\mathrm{ab}}$ & $44,4 \pm 3,56^{\mathrm{b}}$ \\
-3 & $113,4 \pm 6,50^{\mathrm{b}}$ & $44,0 \pm 3,54^{\mathrm{b}}$ \\
\hline \hline
\end{tabular}

Ket: Angka yang diikuti huruf yang sama pada masing-masing kolom pada setiap perlakuan tidak berbeda nyata pada uji DMRT $\alpha=5 \%$.

Hasil pengamatan struktur anatomi menunjukkan bahwa pada umumnya perlakuan yang diberikan tidak mengakibatkan perubahan struktur anatomi daun yang menyolok. Terdapat beberapa karakter anatomi daun yang dapat berubah karena pengaruh lingkungan. Hasil penelitian ini menunjukkan bahwa karakter anatomi daun yang menyangkut ukuran seperti lebar sel epidermis daun bagian atas tanaman kultur, jumlah dan panjang serta lebar stomata daun bagian bawah tanaman kultur, panjang stomata daun bagian bawah tanaman rumah kaca merupakan karakter anatomi yang dapat berubah karena pengaruh lingkungan. Karakter anatomi seperti jumlah lapisan palisade (1 lapis) yang sama antara tanaman kultur dan rumah kaca dan indeks stomata daun bagian atas yang lebih kecil daripada daun bagian bawah baik pada tanaman kultur maupun rumah kaca merupakan karakter anatomi yang lebih bersifat tetap. Ciri anatomi daun yang berubah dan tetap juga ditemukan pada talas (Colocasia esculenta (L.) Schott) liar yang tumbuh pada dua habitat 
berbeda (Sulistyaningsih dan Dorly, 2000). Dengan kembali normalnya variasi morfologi dan kecepatan pertumbuhan yang terjadi pada tanaman kultur setelah diaklimatisasi dan ditanam dirumah kaca, serta diikuti dengan perubahan ciri-ciri anatomi yang tidak menonjol ini diharapkan perbanyakan tanaman A. cina secara in vitro tidak berpengaruh negatif terhadap produksi senyawa bioaktifnya.

\section{Kesimpulan}

Secara umum perlakuan penggojokan saat inkubasi kultur, konsentrasi BAP, dan posisi buku menunjukkan pengaruh yang kurang nyata terhadap peubah anatomi daun. Variasi bentuk, ukuran, warna dan kandungan klorofil daun tanaman kultur tidak bersifat permanen, sifat-sifat tersebut kembali normal setelah tanaman beradaptasi dengan lingkungan luar.

\section{Daftar Pustaka}

Arnon, D.I. 1949. Copper Enzyme in Isolated Chloroplasts. Polyphenoloxidase in Beta vulgaris. Plant Physiol. 24: 1-15.

Aryanti. 2001. Variasi Kandungan Artemisinin dari Akar Rambut dan Regenerasi Artemisia cina Berg. ex Poljakov sebagai Antikanker. Tesis, Institut Pertanian Bogor, Bogor.

Aryanti, Bintang, M., Ermayanti, T.M. and Mariska, I. 2001. Production of Antileukemic Agent in Untransformed and Transformed Root cultures of Artemisia cina. Abstract of The $2^{\text {nd }}$ Indonesian Biotechnology Conference.

Backer, C.A. and R.B.C. Vanden-Brink Jr. 1965. Flora of Java. Vol. 2. NVP. Noordoff-Gronginen-The Netherlands.

Burkill, I.H. 1966. A Dictionary of the Economic Products of the Malay Peninsula. Vol. 1. Governments of Malaysia \& Singapore, Kuala Lumpur.

Ermayanti, T.M., Andry, Y., Wulandari, D.R. dan Al Hafiizh, E. 2002. Mikropropagasi Artemisia cina dan Artemisia annua. Prosiding Seminar Nasional Pemanfaatan dan Pelestarian Plasma Nutfah.

Fahn, A. 1990. Plant Anatomy. $4^{\text {th }}$ ed. ButterworthHeinemann Ltd. Oxford, London.

Fujiwara, K. and Kozai, T. 1995. Physical Microenvironment and Its Effects. In Aitken-Cristie, J., T. Kozai and M.A.L. Smith (Eds.).
Automation and Environmental Control in Plant Tissue Culture, pp. 319-369. Kluwer Academic. Dordrecht, The Netherlands.

Grace, D.J. 1990. The Anatomy and Morphology of Eucalyptus Roots and Shoots in Vitro. Thesis. Murdoch University, Perth, Australia.

Grieve, M. 1931. A Modern Herbal. Vol. 1. Jonathan Cape, London.

Gunawan, L.W. 1988. Teknik Kultur Jaringan. Laboratorium Kultur Jaringan Tanaman Pusat Antar Universitas (PAU) Bioteknologi IPB, Bogor.

Kitaya, Y., Mohapatra, S.C., Kubota, C. and Kozai, T. 1996. Advantages of Photoautotrophic Micropropagation for Space Agriculture. Proceedings of Workshop on Several Aspects of Plant Growth and Development in Space, pp. 235-244. Tohoku University, Sendai, Japan.

Kozai, T., Tanaka, K., Jeong, B.R. and Fujiwara, K. 1993. Effect of Relative Humidity in the Culture Vessel on the Growth and Shoot Elongation of Potato (Solanum tuberosum L.) Planlets in vitro. J. Japan Soc. Hort. Sci. 62 : 413-417.

Murashige,T. and Skoog, F. 1962. A Revised Medium for Rapid Growth and Bioassays with Tobacco Tissue Cultures. Physiol. Plant. 15 : 473-497.

Sass, J.E. 1951. Botanical Microtechnique. $2^{\text {nd }}$ ed .The Iowa State College Press, Iowa.

Sulistyaningsih, Y.C. dan Dorly. 2000. Anatomi Daun Beberapa Talas (Colocasia esculenta (L.) Schott.) Liar dari Kabupaten Bogor. Laporan Akhir Penelitian-Penelitian. Lembaga Penelitian IPB. Bogor.

Syamsuhidayat, S.S. dan Hutapea, J.R. 1991 Inventarisasi Tanaman Obat Indonesia I. Balai Penelitian dan Pengembangan Kesehatan Departemen Kesehatan RI. Jakarta.

Taji, A.M., Dodd, W.A. and Williams, R.R. 1992. Plant Tissue Culture Practice. University of New England, Armidale.

Tjitrosoepomo, G. 2001. Morfologi Tumbuhan. Ed. 13. Gadjah Mada University Press. Yogyakarta.

Towne, G. and Owensby, C. 1983. Cytokinins Effect on Protein and Chlorophyll Content of Big Blue Stem Leaves. Journal of Range Management 36: 75-77.

Willmer, C.M. 1983. Stomata. Department of Biology, University of Stirling. Longman Inc., New 